\title{
Odnos prema rimokatoličanstvu u ranim radovima Karla Bartha
}

\author{
LIDIJA MATOŠEVIĆ* \\ UDK: 27-662-05Barth, K. • Prethodno priopćenje \\ Primljeno: 5. prosinca 2017. • Prihvaćeno: 26. siječnja 2018.
}

Sažetak: Članak tematizira pitanje odnosa protestantskog teologa Karla Bartha prema rimokatoličanstvu. Usredotočen je na razdoblje Barthova djelovanja kao honorarnog profesora na katedri za reformiranu teologiju Sveučilišta u Göttingenu. Riječ je o formativnom razdoblju, kako za Barthovu teologiju uzetu u cjelini, tako i za njegov odnos prema rimokatoličanstvu. Članak prikazuje genezu Barthova interesa za rimokatoličanstvo, smještajući je u kontekst njegova bavljenja samom protestantskom teologijom i njezinom poviješću, odnosno pretpoviješću u teologiji srednjeg vijeka. U clanku se pritom pokazuje kako se Barthov stav o rimokatoličanstvu mijenja - $i$ to od shvaćanja rimokatoličanstva kao svojevrsne 'hereze' srodne novoprotestantizmu pa do shvaćanja rimokatoličanstva kao oblika teologije i crkvenosti koji svojim, premda problematičnim poimanjem mogućnosti

${ }^{*}$ Doc. dr. sc. Lidija Matošević, Sveučilišni centar za protestantsku teologiju »Matija Vlačić Ilirik«, Ivana Lučića 1A, 10000

Zagreb, Hrvatska, lidija.matosevic@ tfmvi.hr Božje Riječi u govoru Crkve, može upravo protestantskoj teologiji i crkvenosti postati kritičkim poticajem u traganju za njezinim djelomice zatrtim identitetom.

Ključne riječi: Karl Barth, teologija reformacije, protestantizam, novoprotestantizam, rimokatoličanstvo, objava, Sveto pismo, autoritet Crkve.

\section{Uvod}

U jesen 1921. godine Karl Barth stupio je u zvanje honorarnog profesora teologije na Georg-August Sveučilištu u Göttingenu, na novoosnovanoj katedri za reformiranu teologiju, čije osnivanje treba djelomice zahvaliti i crkvenopolitičkom djelovanju reformiranih kršćana u Njemačkoj. ${ }^{1}$

${ }^{1}$ O tome vidi u: M. FREUDENBERG, Karl Barth und die reformierte Theologie: Die Auseinandersetzung mit Calvin, Zwingli und den reformierten Bekenntnissschriften während seiner Göttinger Lehrtätigkeit, NeukirchenVluyn, 1997., 17.-37. 
Sam pak poziv Karla Bartha u zvanje honorarnog profesora bio je izvan uobičajenih akademskih procedura. Barth nije postao sveučilišnim profesorom na temelju stečenog doktorata ili habilitacije, ${ }^{2}$ nego - prema vlastitim Barthovim riječima zahvaljujući izuzetno dobroj akademskoj recepciji njegova komentara Poslanice Rimljanima iz 1919. godine. ${ }^{3}$

Barthov opus ponekad se naziva i protestantskom patristikom. Takva klasifikacija djela Karla Bartha nije neutemeljena, jer za protestantsku teologiju opus Karla Bartha doista i predstavlja podsjetnik na njezin identitet koji je $\mathrm{u}$ autorovo vrijeme bio djelomice zatrt. Prema shvaćanju Karla Bartha, to se zatiranje očitovalo u dva vida. Prvi je biblicističko poistovjećivanje Svetog pisma sa samom objavom, a drugi je pak novoprotestantsko poistovjećivanje objave s ljudskom religioznošću.

$\mathrm{Na}$ tragu onoga što je bilo naznačeno u ponovnim reformatorskim apelima o tome da se sporna pitanja, koja su u ono vrijeme opterećivala kršćanstvo, pokušaju riješiti u ekumenskom dijalogu, odnosno na ekumenskom koncilu, ${ }^{4}$ Barth smatra da je i ponovno pronalaženje dijelom zatrtoga protestantskog identiteta moguće samo u ekumenskom dijalogu. Za njega je u tom smislu od osobite važnosti bio kritički dijalog s rimokatoličanstvom. Utoliko nije nimalo čudno da se upravo Karl Barth našao i među protestantskim teolozima koji su bili pozvani sudjelovati u ulozi promatrača u radu Drugoga vatikanskog koncila.

Barthov dijalog s rimokatoličanstvom u strogom smislu te riječi započeo je u vrijeme njegove profesure na sveučilištu u Münsteru (1925. - 1930.). U Münsteru, koji je bio područje u kojemu je rimokatoličanstvo bilo snažno zastupljeno, Barth se po prvi put u svojoj teološkoj karijeri susreće s katoličkim teolozima, tako da s njima druguje te ulazi u živi dijalog. ${ }^{5}$ No formativna faza koja je odredila osnovne koor-

${ }^{2}$ Karl Barth zapravo nikada nije ni započeo doktorski studij, premda je stekao nekoliko počasnih doktorata.

${ }^{3}$ Usp. K. BARTH, Römerbrief (1919), Zürich, 1985., Vorwort (1963), 8 s.

${ }^{4} \mathrm{O}$ reformatorskim apelima za sazivanje ekumenskog koncila, kao i o literaturi na tu temu vidi u: L. MATOŠEVIĆ, Tko želi pronaći Krista, mora najprije pronaći Crkvu - Protestanti i Koncil u povijesno-teološkoj perspektivi, u: T. MATULIĆ i dr. (ur.), 50. obljetnica svečanog otvaranja i početka Drugoga vatikanskog koncila (1962. - 2012.), Zbornik radova, Zagreb, 2015., 251.

${ }^{5}$ Među ovim teolozima bili su Erich Przywara, Robert Grosche i drugi. O Barthovu boravku u Münsteru te susretu s katoličkim teolozima vidi: W. H. NEUSER, Karl Barth in Münster 1925-1930, Zürich, 1985., 39s.; Usp. E. BUSCH, Karl Barths Lebenslauf, München, 1975., 191.-202. Ovdje je zanimljivo primijetiti da su i istraživači Barthove teologije početak Barthova bavljenja temom rimokatoličanstva 'smjestili' upravo u vrijeme njegova djelovanja u Münsteru (Isto). To slijede i drugi, a među njima i ugledni bartijanac B. L. McCormack. Usp. B. L. McCORMACK, Karl Barth's Critically Realistic Dialectical Theology. Its Genesis and Development 1909-1936, Oxford, 1995., 376s. Zacijelo je jedan od uzroka toga što tek u vrijeme Barthova djelovanja u Münsteru nastaju prvi veći dijelo- 
dinate kako Barthovu dijalogu s rimokatoličanstvom u Münsteru, tako i Barthovu stavu prema rimokatoličanstvu do kraja njegova života, dogodila se prije: već za vrijeme njegova predavačkog djelovanja u Göttingenu (1921. - 1925.). ${ }^{6}$ Ovaj rad nastojat će u glavnim crtama prikazati osnovne Barthove ideje o rimokatoličanstvu, kao i razvoj tih ideja upravo za vrijeme njegove formativne faze i to na sljedeći način. Budući da je formiranje Barthova odnosa prema rimokatoličanstvu za vrijeme njegova djelovanja u Göttingenu nastajalo u kontekstu Barthove kritike novoprotestantizma, tako će se i autorovo formiranje stava prema rimokatoličanstvu promatrati u kontekstu te kritike. Pritom će se rad usredotočiti na dvije osnovne faze autorova odnosa prema rimokatoličanstvu. U prvom će se dijelu baviti Barthovim promatranjem rimokatoličanstva kao svojevrsne paralele novoprotestantizmu, a time i kao teološke opcije koja je - premda na nešto drugačiji način - jednako problematična koliko i novoprotestantizam. $U$ drugom i trećem dijelu rada razmatrat će se Barthovo definiranje te redefiniranje autentičnog protestantskog identiteta. $U$ četvrtom dijelu rada usredotočit će se na posljedice promišljanja o protestantskom identitetu na autorovo mijenjanje stava prema rimokatoličanstvu u smislu zaokreta prema shvaćanju rimokatoličanstva kao teološke opcije koja je ne samo manje problematična od novoprotestantizma već i teološke opcije u kojoj su pojedine vrijednosti na kojima je inzistirala upravo i sama reformacijska teologija sačuvane bolje i jasnije nego u novoprotestantizmu.

\section{Barthova kritika novoprotestantizma te razumijevanje rimokatoličanstva kao svojevrsne paralele 'novoprotestantskoj herezi'}

Karl Barth predstavlja za protestantsku teologiju dvadesetog stoljeća jedan od najupečatljivijih podsjetnika na njezin djelomično zaboravljeni identitet. Autorova potraga za zaboravljenim protestantskim identitetom započinje s njegovim najranijim teološkim spisima, a osobito je znakovito prisutna već u spomenutom komentaru

vi tekstova u kojima se Barth opsežnije i eksplicitnije bavi temom rimokatoličanstva (s posebnim naglaskom na pitanjima ekleziologije, nauka o Bogu te nauka o milosti): Pritom jedan tekst iz razdoblja u Münsteru nosi čak i naslov koji nedvojbeno upućuje na Barthovo eksplicitno zanimanje za rimokatoličanstvo. Riječ je o Barthovu javnom predavanju Der römische Katholizismus als Frage an die protestantische Kirche (1928). Usp. K. BARTH, Vorträge und kleinere Arbeiten (1925-1930), H. Schmidt (ur.), Zürich, 1994., 303.-343.

${ }^{6} \mathrm{Na}$ to je u sklopu šireg istraživanja o Barthovu odnosu prema rimokatoličanstvu ukazala L. MATOŠEVIĆ, Lieber katholisch als neuprotestantisch. Karl Barths Rezeption der katholischen Theologie 19211930, Neukirchen-Vluyn, 2005. A nakon Matošević - te specifično s obzirom na Barthov nauk o Bogu - i A. MARGA, Karl Barth's Dialogue with Catholicism in Göttingen and Münster. Its Significance for His Doctrine of God, Tübingen, 2010. 
poslanice Rimljanima iz 1919.7 To traganje intenzivnije je došlo do izražaja nakon Barthova stupanja na mjesto honorarnog profesora u Göttingenu. Kako u pozadini Barthovih sveučilišnih predavanja i seminara, tako i u pozadini njegovih javnih nastupa u vrijeme njegove profesure u Göttingenu, uvijek iznova stoji pitanje: Predstavlja li suvremeni protestantizam autentični nastavak reformacijskih nastojanja? To pak osobito dolazi do izražaja u Barthovim predavanjima iz teologije reformacije, primjerice u njegovom predavanju o Heidelberškom katekizmu koje održava u zimskom semestru 1921./1922., ${ }^{8}$ potom u onom o Calvinovoj teologiji koje održava u ljetnom semestru 1922. ${ }^{9}$ te o Zwinglijevoj teologiji koje pak održava u zimskom semestru 1922./1923. godine. ${ }^{10}$ To pitanje do izražaja dolazi i u ljetnom semestru 1923. godine kada Karl Barth predaje o teologiji reformiranih vjeroispovijednih spisa. ${ }^{11}$ Ključno pitanje koje Barth u tim tekstovima postavlja suvremenom protestantizmu glasi: $\gg$ Odakle mi kao takvi dolazimo? $\ll{ }^{12}$ No perspektiva Barthova pitanja pritom nije povijesna. Barth propituje u kojoj mjeri ono što misli i govori suvremeni protestantizam $\gg$ stoji na liniji onoga što su utemeljitelji protestantske teologije bili te onoga što su oni mislili i govorili o Bogu, svijetu i čovjeku. $\ll^{13}$

Barthov odgovor na pitanje o tome predstavlja li suvremeni protestantizam autentični nastavak reformacijskih nastojanja $\mathrm{u}$ temelju je negativan, a usko je povezan $\mathrm{s}$ Barthovom kritikom novoprotestantizma, odnosno s protestantskom teologijom koja je nastala pod utjecajem novoprotestantizma. ${ }^{14}$ Prema shvaćanju Karla Bartha,

\footnotetext{
${ }^{7}$ Usp. K. BARTH, Römerbrief (1919), Vorwort (1963.), 8s.

${ }^{8}$ Usp. K. BARTH, Der Heidelberger Katechismus, Vorlseung Göttinger Wintersemester 1921/1922 (Karl Barth-Archiv Basel).

${ }_{9}^{9}$ Usp. K. BARTH, Die Theologie Calvins (1922), H. Scholl (ur.), Zürich, 1993.

${ }^{10}$ Usp. K. BARTH, Die Theologie Zwinglis, Vorlesung Göttingen Wintersemester 1922/23 (Karl BarthArchiv Basel)

${ }^{11}$ Usp. K. BARTH, Die Theologie der reformierten Bekenntnisschriften (1923), E. Busch (ur.), Zürich, 1998.
}

${ }^{12}$ Usp. K. BARTH, Die Theologie Calvins (1922), 16.

${ }^{13}$ Isto.

${ }^{14}$ Novoprotestantizam predstavlja skupni naziv za niz tijekova u protestantskoj teologiji koji su se, djelomice i kao posljedica prosvjetiteljskog utjecaja, odvijali od početka devetnaestog stoljeća te su na nju utjecali sve do dvadesetog stoljeća. Najvažnijim predstavnikom novoprotestantizma smatra se F. D. Schleiermacher (1768. - 1834.), dok je sam termin novoprotestantizam profilirao Ernst Troeltsch (1865. - 1923.), suprotstavljajući pritom novoprotestantizam tzv. staroprotestantizmu. Pritom je pod staroprotestantizmom podrazumijevao protestantsku teologiju nakon reformacije koja nije bila do kraja oslobođena od problematičnih ostataka srednjovjekovne teologije te uopće utjecaja autoritarne srednjovjekovne kulture. Prema Troeltschu, odlučujuća promjena koju uvodi novoprotestantizam - zbog čega upravo novoprotestantizam predstavlja istinsko ostvarenje reformacijskih ideala - jest raskid sa svakim oblikom izvanjskog autoriteta: bilo da je riječ o autoritetu 
novoprotestantizam, koji je bitno odredio protestantsku teologiju u devetnaestom i dvadesetom stoljeću, ne predstavlja nastavak razvoja autentične teologije reformacije, nego njezinu dekadenciju. Tako je od teologije reformacije, koja je sebi kao jedan od sržnih ciljeva postavila ponovno progovaranje o Bogu, u skladu s onim što je Bog sam progovorio o sebi u svojoj objavi, nastala teologija koja govor o Bogu zamjenjuje govorom o ljudskoj religioznosti. Takav stav Barth više puta izriče kako u svojim sveučilišnim, tako i u javnim predavanjima tijekom svojega djelovanja u Göttingenu. ${ }^{15}$

Taj Barthov stav sam po sebi ne predstavlja, međutim, ništa novo u odnosu na njegov dotadašnji opus. Jer kritika novoprotestantizma kao dekadencije u odnosu na autentičnu reformacijsku teologiju utkana je i u Barthove prijašnje radove. Ona je tako jasno izrečena u komentaru poslanice Rimljanima iz 1919. godine, ${ }^{16}$ kao i u pojedinim autorovim javnim predavanjima iz istoga razdoblja. ${ }^{17}$

Ono po čemu se Barthova kritika novoprotestantizma u Göttingenu razlikuje od njegove dotadašnje kritike novoprotestantizma jest u tome što sada u svoju kritiku novoprotestantizma, odnosno u svoje suprotstavljanje novoprotestantizma autentičnom reformacijskom protestantizmu, 'upleće' i treći pojam, a to je rimokatoličanstvo.

Proces u kojemu je do toga došlo mogao bi se sažeti na sljedeći način. Kako bi - za sebe i za svoje studente - traganje za identitetom autentičnog protestantizma učinio temeljitijim, Barth se najprije posvećuje studiju razdoblja teologije reformacije. Zbog toga nije nimalo slučajno što njegova predavanja u prvoj (1921./1922.), a dijelom i u drugoj akademskoj godini (1922./1923.) njegova predavačkog djelovanja u Göttingenu nose naslove povezane upravo s teologijom reformacije. ${ }^{18}$ Po-

Crkve, bilo da je riječ o autoritetu Biblije. Pritom novoprotestantizam zamjenjuje oslanjanje na izvanjske autoritete oslanjanjem na autoritet religijske samosvijesti pojedinca, odnosno na autoritet religijskog iskustva. Terminološko razlikovanje 'novoprotestantizma' i 'staroprotestantizma', kao i vrednovanje 'novoprotestantizma' kao takvoga koji nadilazi 'staroprotestantizam', osobito je artikulirano u Troeltschevoj knjizi: E. TROELTSCH, Die Bedeutung des Protestantismus für die Entstehung der modernen Welt, Berlin, 1911., 25ss.

${ }^{15}$ Takav je stav opsežno artikuliran u ciklusu predavanja o Calvinovoj teologiji. Usp. K. BARTH, Die Theologie Calvins (1922), 28.-66. Među Barthovim javnim predavanjima koja posebno podcrtavaju takav stav posebice se ističe njegovo predavanje 'Das Wort Gottes als Aufgabe der Theologie (1922)'. Usp. K. BARTH, Das Wort Gottes als Aufgabe der Theologie (1922), u: ISTI, Vorträge und kleinere Arbeiten (1922-1925), H. Finze (ur.), Zürich, 1990., 144.-176.

${ }^{16}$ Usp. K. BARTH, Römerbrief (1919), 581s., 587., 595ss.

${ }^{17}$ U tom se smislu osobito ističe Barthovo predavanje 'Der Christ in der Gesellschaft (1919)'. Usp. K. BARTH, Der Christ in der Gesellschaft (1919), u: ISTI, Wort Gottes und die Theologie, München, 1925., 33.-69.

${ }^{18}$ Usp. K. BARTH, Der Heidelberger Katechismus; ISTI, Die Theologie Calvins (1922); ISTI, Die Theologie Zwinglis. Vorlesung Göttingen Wintersemester 1922/23. 
čevši izučavati teologiju reformacije Barth, međutim, vrlo brzo uviđa da upravo tu teologiju neće moći razumjeti ukoliko se prije toga temeljito ne upozna s teologijom srednjega vijeka čiju je kritiku teologija reformacije barem u jednom dijelu i predstavljala. Za Bartha je to bila nova i iznimno zahtjevna situacija. Stoga je često imao osjećaj da neće stići pravovremeno proučiti građu te se pripremiti za svoja predavanja. ${ }^{19}$

Kao što je spomenuto, Barthov zaključak o novoprotestantizmu koji je iz ovog studija proizašao, donekle se razlikuje od njegova dotadašnjeg suda o novoprotestantizmu. Barth tako zaključuje ne samo ono što je već prije bio ustvrdio, primjerice u komentaru Poslanice Rimljanima (1919.), a to je da novoprotestantizam predstavlja 'hladnokrvnu' izdaju evanđelja, a time i teologije reformacije ${ }^{20}$, nego i to da novoprotestantizam pokazuje određenu srodnost upravo teologiji srednjeg vijeka. Utoliko, prema Barthu, srednji vijek nije samo nastavio živjeti u rimokatoličkoj teologiji koja je - posve smjerno, ponosno i dosljedno - nastavila graditi na srednjovjekovnoj tradiciji, nego i u novoprotestantizmu čija je, prema autoru, osnovna boljka svojevrsna prikrivena 'nostalgija za Rimom. ${ }^{21}$ To je osobito snažno artikulirano u okviru Barthovih predavanja o Calvinovoj teologiji, posebice u dijelu tih predavanja pod naslovom $\gg$ Reformacija i srednji vijek $<\mathrm{u}$ kojemu se neprestano provlači misao o srodnosti novoprotestantizma srednjovjekovnoj teologiji. ${ }^{22}$ Takvim se shvaćanjem Karl Barth izravno suprotstavio novoprotestantskom shvaćanju prema kojemu se protestantska teologija upravo u svom novoprotestantskom obličju konačno oslobodila utjecaja autoritarne kulture srednjovjekovlja. ${ }^{23}$

Zaključivši da i novoprotestantizam i rimokatoličanstvo imaju svoj temelj u srednjem vijeku, Barth je potom došao do zaključka o srodnosti novoprotestantizma i rimokatoličanstva. Barthova argumentacija takvog stava mogla bi se sažeti na sljedeći način. I novoprotestantizam i rimokatoličanstvo (odnosno teologija srednjeg vijeka) predstavljaju pokušaj da se govor o Bogu, koji je moguć samo u Božjoj samoobjavi, pretvori u jednostavno ljudski govor, odnosno u govor o čovjeku. Sred-

${ }^{19} \mathrm{O}$ ovim svojim mukama i čestoj panici pri pripremanju predavanja Barth redovito piše svom prijatelju Thurneysenu. Usp. K. BARTH, E. THURNEYSEN, Briefwechsel II (1921-1930), Zürich, 1974., 60.

${ }^{20}$ Usp. K. BARTH, Römerbrief (1919), Vorwort III, 595.

${ }^{21}$ Izraz $\gg$ nostalgija za Rimom « kao opis boljke suvremenog protestantizma učestao je u Barthovim tekstovima iz ovog razdoblja. Ta se ideja provlači i kroz njegovu korespondenciju s prijateljem Thurneysenom. Primjerice, Barth mu tako piše 22. siječnja 1922.: »Ne misliš li i ti, Eduarde, da je to nekako naše mjesto: ondje u sjeni prije reformacije, dok još nije bilo 'izvjesnosti spasenja' ni 'evangeličke slobode' itd.« K. BARTH, E. THURNEYSEN, Briefwechsel II (1921-1930), 30.

${ }^{22}$ Usp. K. BARTH, Die Theologie Calvins (1922), 15.-92.

${ }^{23}$ Usp. isto, 16. 
njovjekovna teologija - koju Barth, služeći se Lutherovim terminom theologia gloriae opisuje kao $\gg$ hrabru, sigurnu teologiju, te teologiju svjesnu pobjede $\ll^{24}$ učinila je to - smatrajući govor Crkve svojevrsnim nastavkom objave - putem poistovjećivanja tog govora sa samom objavom. Novoprotestantizam pak učinio je to poistovjećujući religijsko iskustvo pojedinca, odnosno vjerničke zajednice, s govorom o samoj Božjoj zbilji. Stoga, prema Barthu, novoprotestantska romantika te novoprotestantska zamisao o autoritetu neposrednog vjerničkog iskustva ne predstavlja ništa drugo nego svojevrsnu inačicu rimokatoličke teologije. Novoprotestantizam time dokazuje koliko je rimokatolička teologija probojna i impozantna te koliko je teško oduprijeti se njezinu sjaju, privlačnosti te osjećaju sigurnosti koji ona pruža te se doista profilirati kao protestantska alternativa koja bi bila i vrijedna spomena. ${ }^{25}$ Ovdje je važno napomenuti i to da je za Bartha novoprotestantizam, premda ga on smatra svojevrsnom inačicom srednjovjekovne odnosno rimokatoličke teologije, samo loša inačica koja kao takva nikada ne može parirati svome uzoru koji - htjela si to ona priznati ili ne - zapravo pokušava relativno neuspješno imitirati. Za Bartha je stoga srednjovjekovna odnosno rimokatolička teologija - i bez obzira na to što se on ne slaže s nekim njezinim dijelovima - vrijedna divljenja i poštovanja, dok je novoprotestantizam zapravo samo svojevrsna tužna slika i prilika izgubljenoga protestantskog identiteta. ${ }^{26}$

\section{Barthovo definiranje autentičnog protestantskog identiteta u ranoj göttingenškoj fazi}

Prema onome što Barth tvrdi u ranijoj fazi svojega djelovanja u Göttingenu (1921./1922.), autentična protestantska alternativa kako srednjovjekovlju i rimokatoličanstvu tako i novoprotestantizmu u tome je da se ne bježi od muke i permanentne krize koja, prema Barthu, pripada u bit kršćanstva vjernom evanđelju i

${ }^{24}$ Usp. isto, 40. Prema Barthu, to je teologija u kojoj je odnos između Boga, čovjeka i svijeta shvaćen kao odnos različitih veličina, ali takvih koje ipak stoje u kontinuitetu. To je teologija koja ne poznaje principijelno suprotstavljanje između objave i razuma, biblijskog i crkvenog autoriteta te u konačnici teologija koja nikada ne dolazi do posljednjeg 'ili-ili' (Isto, 40ss).

${ }^{25}$ Problem s ovakvim neuspješnim 'odupiranjem' protestantska teologija, prema Barthu, pokazuje već od vremena neposredno nakon reformacije kada se ona - čim su osnivači reformacije isčeznuli s teološke scene - požurila vratiti srednjovjekovnoj tradiciji i to ponajprije u vidu protestantske ortodoksije, a zatim i u vidu pijetističke tradicije. (Usp. isto, 32s.) Upravo stoga Barth ironično primjećuje: $\gg$ Ne bi li bilo bolje da se vratimo unatrag? Da umjesto s Calvinom zaključimo ovaj semestar s Tomom, kao duhom koji ustvari bolje razumijemo?« (Isto, 53.)

${ }^{26}$ Osobito je Barthovo predavanje o Calvinovoj teologiji prepuno izričaja divljenja srednjovjekovnoj odnosno rimokatoličkoj teologiji kao takvoj koja je prodorna, svježa i konsekventna, pri čemu su ti izričaji vrlo često isprepleteni sa zdvajanjem nad otužnom situacijom Barthu suvremenog protestantizma. (Usp. isto, 32ss.) 
reformacijskim načelima, a time i u bit reformaciji vjerne protestantske teologije. Muka i tjeskoba o kojoj je ovdje riječ proizlazi iz svijesti o Božjoj drukčijosti u odnosu na sve tvorevine ljudske kulture te ljudske religije, uključujući i onu kršćansku. To je ono što egzistenciju autentičnoga protestantskog teologa kao i autentičnoga protestantskog vjernika čini egzistencijom na uzburkanom moru gdje nema osjećaja sigurnosti, gdje je čovjek raspet u dijalektici između ljudskog vremena i Božje vječnosti. ${ }^{27} \mathrm{U}$ ovakvoj maniri dijalektičke teologije Barth kroči kroz čitav dio posvećen povijesti reformacije u svom ciklusu o Calvinovoj teologiji, pod naslovom $\gg$ Luther, Calvin i Zwingli $\ll^{28}$. Takvo pak shvaćanje biti reformaciji vjernog kršćanstva na posebno zgusnut način dolazi do izražaja u Barthovu predavanju Not und Verheissung der christlichen Verkündigung koje je održao u srpnju 1922. godine. ${ }^{29}$ Tu Barth tjeskobu i muku reformacijskim načelima odanog protestantizma opisuje na primjeru protestantskog propovjednika koji - za razliku od rimokatoličkog koji stoji za oltarom i visoko podiže hostiju, u kojoj se, prema Barthu, najsnažnije i najzornije, očituje sigurnost i izvjesnost koju pruža rimokatoličanstvo - stoji za propovjedaonicom duboko svjestan svoje zadaće propovijedanja, ali isto tako i svoje ograničenosti i nemogućnosti da uistinu progovori o Bogu kao bitno drukčijem, odnosno da uistinu progovori Riječ Božju. ${ }^{30}$ Situacija reformaciji vjernog protestantizma kao situacija permanentne krize koja podjednako vrijedi za teologe i za one koji propovijedaju ${ }^{31}$ gotovo je programatski sumirana u Barthovu javnom

\footnotetext{
${ }^{27}$ Autentična protestantska teologija život čini problemom, zadaćom i mukom. Ona stoga, za razliku od sigurnoga rimokatoličkog tla, može poslužiti isključivo kao »utočište za nuždu «, a nikako kao »solidno sazdana kuća «. (Isto, 53.)

${ }^{28}$ Usp. isto, 93.-171.

${ }^{29}$ Usp. K. BARTH, Not und Verheissung der christlichen Verkündigung (1922), u: ISTI, Vorträge und kleinere Arbeiten (1922-1925), Zürich, 1990., 65.-97.

${ }^{30}$ Usp. isto, 80ss. Barth je, dakako, svjestan toga da nam je kao kršćanima dano obećanje da ćemo upravo kao ljudi moći progovarati Božju Riječ. No Barth jasno naznačuje da obećanje nije nužno i ispunjenje: »Obećanje nije ispunjenje (...) ono samo znači da nam je ispunjenje obećano. « Stoga nastavlja: »Pa sasvim je jasno: (...) mi možemo samo vjerovati da govorimo Božju riječ. Jer Božja riječ na usnama čovjeka - to nije moguće, to se ne događa, tome ne možemo težiti niti to možemo ostvariti. Božja riječ (...) mora biti i ostati Božja riječ.« (Isto, 89s.) Očito aludirajući na novoprotestantsku duhovnost, Barth pokušaj svih onih koji, koristeći određena religijska opojna sredstva, pokušavaju od protestantizma načiniti sigurno tlo, kvalificira kao $\gg$ krajnju pretencioznost, krajnju megalomaniju i - da se izrazimo manje klasično, ali utoliko jasnije - krajnji kič! « (Isto, 90.)

${ }^{31}$ Ovdje valja primijetiti da je poistovjećivanje zadaće, a time i situacije protestantskog teologa sa situacijom protestantskog propovjednika tipično za ranije razdoblje Barthova djelovanja u Göttingenu. U kasnijim tekstovima, uključujuči i one u kasnijem razdoblju njegova djelovanja u Göttingenu, Barth će započeti razlikovati ulogu propovjednika (odnosno navještaja Crkve) i ulogu teologa. Usp. M. BEINTKER, Die Dialektik in der 'dialektischen Theologie' Karl Barths. Studien zur Entwicklung der Bartschen Theologie und zur Vorgeschichte der 'Kirchlichen Dogmatik', München, 1987., 141s.
} 
predavanju Das Wort Gottes als Aufgabe der Theologie koje je Barth održao u listopadu 1922. godine. Barth tu kaže: »Mi kao teolozi moramo govoriti o Bogu. No mi smo i ljudi, a kao takvi ne možemo govoriti o Bogu. Trebamo biti svjesni jednoga i drugog, svojeg moranja i svoje nemogućnosti i upravo time dati Bogu slavu $\ll .{ }^{32}$ Barth pritom sasvim odlučno - osobito aludirajući na novoprotestantskog teologa Schleiermachera - svaki teološki pokušaj da se ovoj neizdrživoj muci doskoči opisuje kao protestantsku teologiju kojoj nije sasvim jasna njezina osnovna postavka, a to je da govoriti o Bogu »znači nešto drugo, doli nešto uzvišenijim glasom govoriti o čovjeku $\ll^{33}$.

\section{Redefiniranje protestantizma vjernog reformacijskim načelima u drugoj fazi Barthova djelovanja u Göttingenu}

Do redefiniranja Barthova stava o protestantizmu vjernom reformacijskim načelima dolazi korak po korak. A taj bi se put mogao opisati kao put od razumijevanja reformaciji vjernog protestantizma kao takvoga koji je bitno određen krizom te nemogućnošću da govori o Bogu, prema razumijevanju reformaciji vjernog protestantizma prema kojemu ovaj - premda drukčije nego što to čini rimokatoličanstvo - govori o mogućnosti ljudskog govora o Bogu te o mjeri izvjesnosti i sigurnosti koja je s takvom mogućnošću povezana. Tako se u Barthovu sliku protestantske teologije koja se nalazi u nemogućoj situaciji postupno uvlači ponešto svjetlosti. Naznake takve promjene u vrednovanju reformaciji vjernog protestantizma prisutne su dijelom već i u predavanju Das Wort Gottes als Aufgabe der Theologie (1922). Premda je, naime, tema ovog predavanja nemogućnost Riječi Božje na ljudskim usnama, Barth na njegovu kraju ipak izražava nadu u mogućnost da obećanje ipak postane i ispunjenje te da tako naše ljudske riječi postanu barem zemljanim posudama Riječi Božje. ${ }^{34}$ Riječ je o naznaci toga da onome koji nastoji egzistirati na protestantski autentičan način u konačnici ipak ne preostaje biti isključivo »svetopisamskim « teologom, odnosno o naznaci da postoji mogućnost ljudskog, odnosno crkvenog govora o Bogu - i mimo onoga u svetopisamskom kanonu. A ta pak mogućnost počiva na stvarnosti utjelovljenja, odnosno na događaju Božje samoo-

\footnotetext{
${ }^{32}$ Usp. K. BARTH, Das Wort Gottes als Aufgabe der Theologie (1922), 151.

${ }^{33}$ Usp. isto, 158. Zanimljivo je ovdje reći da se ocjena Barthove teologije kao teologije koja upravo svojim naglašavanjem ljudske nemogućnosti da govori o Bogu predstavlja povratak autentičnoj teologiji reformacije nalazi i kod Barthu suvremenog rimokatoličkog teologa Ericha Przyware. S tom, dakako, razlikom što Przywara ne zastupa i Barthovo mišljenje o tome kako teologija novoprotestantizma predstavlja svojevrsnu inačicu srednjovjekovne odnosno rimokatoličke teologije. Usp. E. PRZYWARA, Gott in uns und Gott über uns? Immanenz und Transzendenz im heutigen Geistesleben, u: Stimmen der Zeit 105(1923.), 343.-362.

${ }^{34}$ Usp. K. BARTH, Das Wort Gottes als Aufgabe der Theologie (1922), 174s.
} 
bjave u Isusu Kristu. ${ }^{35}$ No krizna situacija nije time razriješena. To je tako jer, prema Barthu, između naših ljudskih riječi i Riječi Božje u Kristu ne postoji izravni kontinuitet, nego smo u procesu naviještanja upućeni na prvotne svjedoke te Riječi te je tako jedina mogućnost navještaja kršćanske Crkve kao i teološkog rada vjerovati tom svjedočanstvu. ${ }^{36}$ Sveto pismo time je za Bartha shvaćeno s jedne strane kao uporište, ali s druge strane u isto vrijeme i kao ograničenje ljudske mogućnosti da progovori Riječ Božju, čime je, prema Jüngelu, kod Bartha u ovom razdoblju ipak u temelju očuvana ideja o nepremostivoj distanci između kršćanskog navještaja i same kristologije. ${ }^{37}$

Da ova distanca ipak nije nepremostive naravi, nagovještaju Barthovi tekstovi iz 1923. godine, prema kojima egzistencija protestantskog vjernika, odnosno protestantske Crkve izgleda bitno podnošljivijom. U tom se smislu osobito ističe Barthovo javno predavanje Reformierte Lehre, ihr Wesen und ihre Aufgabe ${ }^{38}$ koje je održao u rujnu 1923. te ciklus sveučilišnih predavanja o teologiji reformiranih ispovjednih spisa koji Barth održava u ljetnom semestru 1923. godine. ${ }^{39} \mathrm{U}$ oba teološka rada jedno je od ključnih pitanja ono o mogućnosti ljudskog govora o Bogu. I sada Barth ustraje na stavu da Bog može govoriti samo sam o sebi te da je svjedočanstvo o Božjoj samoobjavi sadržano samo u svetopisamskim tekstovima. No konsekvencije koje Barth izvodi iz tog stava razlikuju se od onih u njegovim prijašnjim tekstovima. Naime, dok u spomenutom predavanju Barth još govori o krizi i nemogućnosti govora o Bogu kao o konačnim datostima reformacijskim načelima vjernog protestantizma te jedinu mogućnost kršćanskog teologa i propovjednika kao i cjelokupnog protestantskog crkvenog navještaja vidi u tome da se vjerom osloni na svjedočanstvo o Isusu Kristu prvotnih svjedoka tog događaja i tako ne pokušava biti ništa više od »svetopisamskog « teologa, u tekstovima iz 1923. godine Barth otvara pitanje o odgovornom teološkom govoru kršćanske Crkve. Preciznije rečeno, Barth ovdje ulazi u diskurs o mogućnosti kršćanskog nauka, odnosno doktrine. Istina, kršćanski nauk o kojemu je ovdje riječ još uvijek nije shvaćen kao sama Riječ Božja - jer Riječ Božju može, tvrdi Barth i dalje, progovoriti samo Bog sam. ${ }^{40}$ No

\footnotetext{
${ }^{35}$ Usp. isto, 219.

${ }^{36}$ Usp. isto, 175.

${ }^{37}$ Tako Barth: »Može li teologija preko prolegomena ikada dospjeti do kristologije, i treba li uopće? Pa možda je s prolegomenama sve već rečeno.« (Isto, 175.) Prema Jüngelu se, ipak, u ovom tekstu, zamjećuje prvo Barthovo relativiziranje dijalektike. O tome vidi u: E. JÜNGEL, Von der Dialektik zur Analogie, u: ISTI, Barth-Studien, Köln - Zürich, 1982., 129.

${ }^{38}$ Usp. K. BARTH, Reformierte Lehre, ihr Wesen und ihre Aufgabe (1923), u: ISTI, Vorträge und kleinere Arbeiten (1922-1925), Zürich, 1990., 202.-247.

${ }^{39}$ Usp. K. BARTH, Die Theologie der reformierten Bekenntnisschriften (1923).

${ }^{40}$ Usp. K. BARTH, Reformierte Lehre, ihr Wesen und ihre Aufgabe (1923), 224s.
} 
unatoč ovom jasnom odbijanju bilo kakve identifikacije kršćanskog govora odnosno kršćanskog nauka s Riječju Božjom, Barth u svojim tekstovima iz ovog razdoblja jasno i nedvosmisleno progovara o mogućnosti i potrebi kršćanskog nauka. Pritom pak podsjeća kako reformacija nije započela šutnjom, nego propovijedima i predavanjima, a to znači jasnim i artikuliranim govorom o Bogu ${ }^{41}$ Mijenjajući tako $\mathrm{u}$ isto vrijeme i ton i sadržaj svojega dotadašnjeg teološkog razmišljanja, Barth tvrdi kako upravo zato i povratak $\mathrm{k} \gg$ starom svetom reformacijskom nasljeđu « podrazumijeva propitivanje o biti i zadaći jasnoga i artikuliranog kršćanskog nauka. ${ }^{42} \mathrm{~A}$ to pak u konačnici znači da se obnova autentične protestantske teologije ne iscrpljuje u šutnji i zamuckivanju, nego u preispitivanju primjerenog odnosa između Svetog pisma i govora Crkve, odnosno crkvenog nauka. Prema tekstovima iz ovog razdoblja taj bi se odnos mogao sažeti kao odnos gdje se zadaću Crkve, odnosno njezinog nauka opisuje kao takvu gdje se Crkva u najboljem slučaju usuđuje progovoriti o Bogu, svijetu i čovjeku i to tek nakon što Sveto pismo prvo progovori. ${ }^{43}$ Upravo se stoga riječ Crkve, odnosno riječ njezina nauka ne može kvalificirati kao verbum divinum, nego u najboljem slučaju kao predicatio verbi divini.$^{44}$ Pritom je domet predicatio verbi divini isključivo u tome da ljudskim riječima izrekne ono što je čovjeku već prije toga izrečeno božanskim riječima, ali zapravo i ništa više od toga ${ }^{45}$ - jer kršćanski je nauk, kao i cijeli govor Crkve još uvijek samo ljudska riječ koja je prošla kroz katarzu Riječi Božje zasvjedočene u Svetome pismu. ${ }^{46}$

Još značajniji pomak, u usporedbi s tezom o nemogućnosti ljudskog govora o Bogu s početka Barthova djelovanja u Göttingenu, do izražaja dolazi u Barthovim predavanjima iz dogmatike koja je održao u akademskoj godini 1924./1925., a koja su sažeta u dva sveska pod naslovom Unterricht in der christlichen Religion ${ }^{47}$, a pritom aludirajući na Calvinove Institutio christianae religionis. Do tog je pomaka došlo na sljedeći način. Naime, za Bartha je zadaća održavanja predavanja iz dogmatike predstavljala ogroman radni izazov, budući da je - kao i pri pripremama za predavanja o Calvinovoj teologiji - osjećao deficit u poznavanju materije, osobito one iz povijesti teologije. Upravo je zato, tijekom priprema ovih predavanja, neprestano i sam izučavao povijesno-teološka razdoblja: počevši od razdoblja patristike, preko

\footnotetext{
${ }^{41}$ Usp. isto, 209.

${ }^{42}$ Usp. isto, 210.

${ }^{43}$ Usp. isto, 223.

${ }^{44}$ Usp. isto, 218.

${ }^{45}$ Usp. isto.

${ }^{46}$ Usp. isto, 229s.

${ }^{47}$ Usp. K. BARTH, Unterricht in der christlichen Religion (1924), I, H. Reiffen (ur.), Zürich, 1985.; ISTI, Unterricht in der christlichen Religion (1924/1925), II, H. Stoevesandt (ur.), Zürich, 1990.
} 
razdoblja srednjovjekovne teologije te teologije reformacije, pa sve do razdoblja tzv. novoprotestantizma. ${ }^{48}$ Pritom osobitu Barthovu pažnju zadobiva protestantska ortodoksija, a posebno njezina kalvinistička/reformirana verzija. A najveću pak Barthovu pažnju privukla je dogmatika reformiranog teologa, odnosno dogmatičara i povjesničara crkve iz 19. stoljeća Heinricha Heppea. ${ }^{49}$ Prema Barthovim vlastitim izričajima, ono novo i prosvjetljujuće što je susreo u toj dogmatici nije bio toliko njezin sadržaj sam po sebi - jer je Heppeova dogmatika u jednom svom dijelu bila usmjerena i na teologiju F. D. Schleiermachera koga je Karl Barth već godinama bio oštro kritizirao - već njezina metodologija. A tu pak metodologiju Barth opisuje kao metodologiju dogmatike koja jest usmjerena na Sveto pismo, odnosno na biblijsko svjedočanstvo o objavi, ali jednako tako i na nauk Crkve sagledan tijekom cijele njezine povijesti: od patristike, preko srednjeg vijeka, teologije reformacije te teologije protestantske ortodoksije, ne isključujući ni govor suvremene zajednice vjernika. Desetak godina poslije Barth će, u predgovoru ponovljenom izdanju ovog djela, svoj prvi susret s tom dogmatikom opisati kao susret koji mu je pomogao da se i sam nađe $\gg$ u prostoru Crkve $\ll$ ${ }^{50}$.

Stupanje $\mathrm{u} \gg$ prostor Crkve « imalo je i važne posljedice za Barthovo razumijevanje naravi reformaciji vjernog protestantizma. Za razliku od Barthovih ranijih izričaja o tome kako se najviši domet koji može postići crkveni navještaj sastoji od svojevrsnog zamuckivanja koje proizlazi iz svijesti o nemogućnosti Riječi Božje na ljudskim usnama, u svojoj göttigenškoj domatici Barth po prvi put jasno i glasno tvrdi kako je navještaj kršćanske Crkve također Riječ Božja. Ali ne samo to. Jer, prema Barthovim riječima - a takvi su obrati tipični za Bartha u formativnoj fazi razvoja njegove teologije - namjera je njegove göttingenške dogmatike razračunati se s mišljenjima koja tvrde suprotno te poriču Riječ Božju u navještaju Crkve. Dakako da je to uključivalo i Barthovo implicitno razračunavanje s njegovim vlastitim ranijim stavovima. ${ }^{51}$

Barth tako u göttingenškoj dogmatici progovara o hrabrosti kršćanske Crkve da progovori samu Riječ Božju te da tako njezin navještaj bude više od predicatio verbi divini o kojoj je Barth govorio u tekstovima iz 1923. godine. ${ }^{52}$ Ta pak hrabrost od koje Crkva ne smije odustati - a koja u konačnici predstavlja hrabrost Crkve kao cjeline - posebno dolazi do izražaja na propovjedaonici, iako nije na nju ograniče-

\footnotetext{
${ }^{48}$ Usp. K. BARTH, E. THURNEYSEN, Briefwechsel II (1921-1930), 224., 236.

${ }^{49}$ Usp. H. HEPPE, Die Dogmatik der evangelisch-reformierten Kirche, Neukirchen, 1935.

${ }^{50}$ Isto, VIf. Podrobnije o Barthovu bavljenju ovom dogmatikom vidi u: R. H. R. BROWER, Karl Barth and Post-Reformation Orthodoxy, London - New York, 2016., 3ss.

${ }^{51}$ Usp. K. BARTH, Unterricht in der christlichen Religion (1924), I, 61 ss.

${ }^{52}$ Usp. K. BARTH, Reformierte Lehre, ihr Wesen und ihre Aufgabe (1923), 218.
} 
na. ${ }^{53}$ Barth pritom i dalje tvrdi kako je naviještanje kršćanske Crkve strogo navezano na kanon kao »kvalificirani historijski datum « te kako na kanon, kao na mjerilo na kojemu se preispituje njegova vjerodostojnost samoj objavi, treba i ostati usmjereno. ${ }^{54}$ Taj stav ne priječi, međutim, Bartha u tome da jasno i glasno kaže kako je za Crkvu upravo sam kanon i njegov sadržaj u isto vrijeme i zapovijed ( $\gg$ Gebot $\ll$ ) da dalje pronosi svjedočanstvo o objavi koje je sadržano u kanonu kao u svjedočanstvu, odnosno da dalje pronosi samu Riječ Božju koja je predana u objavi. I to tako da upravo Crkva, odnosno zajednica vjernika, i sama progovara tu samu Riječ Božju u vremenu u kojemu živi. ${ }^{55}$ Štoviše, oni koji poriču mogućnost Riječi Božje u navještaju Crkve, bilo kroz njezinu povijest, bilo u govoru suvremene zajednice vjernika, prema Barthu, na lošem su putu koji bi ih mogao odvesti čak i dotle da na kraju poreknu i Riječ Božju u Svetome pismu. Štoviše, prema Barthu, onima koji poriču mogućnost Riječi Božje u govoru suvremene Crkve moglo bi se dogoditi čak i to da tu Riječ poreknu i u samom događaju objave te da tako u pitanje dovedu i pouzdanje u vjerodostojnost same objave. ${ }^{56}$ Dakako, govor zajednice vjernika i dalje je za Bartha pothvat spojen s različitim rizicima. I u tom je smislu Crkva dužna uvijek iznova vraćati se kanonu. No upravo je, prema Barthu, taj toliko bitan povratak kanonu moguć samo u Crkvi te ga upravo zato i nije uputno provoditi jednostavno ignorirajući ili zanemarujući govor zajednice vjernika kako u prošlosti tako i u sadašnjosti. ${ }^{57} \mathrm{U}$ pozadini takvog zaokreta $\mathrm{u}$ stavovima nalazi se Barthovo razumijevanje Riječi Božje koja se javlja u tri vida ili obličja ( $\gg$ Gestalt «): kao Riječ u samom događaju objave, kao Riječ u svetopisamskom svjedočanstvu te kao Riječ u navještaju zajednice vjernika. ${ }^{58}$ To shvaćanje, koje će svoju precizniju artikulaciju dobiti tek u Barthovoj Crkvenoj dogmatici, polazi od toga kako je i u događaju same objave, i u njezinom svetopisamskom svjedočanstvu, ali i u govoru Crkve / zajednice vjernika na djelu ista Riječ Božja. ${ }^{59}$ Stoga te vidove Riječi Božje nije moguće ni dijeliti ni odvajati, nego tu imamo posla, prema Barthu, $\mathrm{s} \gg$ unitas in trinita-

\footnotetext{
53 »Hrabrost kršćanskog propovjednika ujedno je i hrabrost kršćanske Crkve. Kršćanski propovjednik nije samo 'pojedinac' kako ga je prikazao Kierkegaard (...) Time što govori o Bogu, on se smješta u određeni niz, na osnove specifičnog dijela povijesti, u određeni poredak.« K. BARTH, Unterricht in der chrislichen Religion (1924), I, 63.

${ }^{54}$ Usp. isto.

${ }^{55}$ Usp. isto.

${ }^{56}$ Usp. isto, 60ss. Opširnije o tom zaokretu vidi u: M. BEINTKER, Die Dialektik in der 'dialektischen Theologie' Karl Barths, 146ss.

${ }^{57}$ Barth je u tom smislu odlučan: »Božja riječ u Svetome pismu do mene dolazi samo u obliku autoriteta zajednice $(. ..) \ll \mathrm{K}$. BARTH, Unterricht in der christlichen Religion (1924), I, 281. Usp. isto, 285ss.

${ }^{58}$ Usp. isto, 18.

${ }^{59}$ Usp. isto, $18 \mathrm{~s}$.
} 
te $\ll$ te $\gg$ trinitas in unitate $\ll$. No, ovaj identitet ne znači da ta tri obličja Riječi Božje nije potrebno razlikovati i nekako stupnjevati. Pri tom razlikovanju i stupnjevanju treba se pak voditi temeljnim načelima. A ta su da Sveto pismo nije sama objava, nego svjedočanstvo koje proizlazi iz objave kao i to da navještaj Crkve, odnosno zajednice vjernika, nije ni sama objava ni Sveto pismo, nego da proizlazi iz obojega. Upravo je zato važno imati na umu da tvrditi mogućnost identiteta navještaja zajednice vjernika sa samom objavom ne znači i apriorno pretpostaviti kontinuitet između događaja objave i govora zajednice vjernika. Štoviše, govoriti o mogućnosti identiteta navještaja zajednice vjernika sa samom objavom znači imati na umu da se između same objave i navještaja Crkve uvijek nalazi Sveto pismo kao svjedočanstvo prvotnih svjedoka o objavi s kojim se ne može mjeriti nijedan kasniji govor Crkve. ${ }^{60} \mathrm{I}$ to je, kako Barth napominje, zbog 'fatalne' i 'brutalne' činjenice da zajednica vjernika koja živi nakon vremena prvotnih svjedoka objave nije vidjela uskrslog Krista te da joj zato, $\mathrm{u}$ odnosu na prvotne svjedoke objave, pripada podređena $\mathrm{i}$ drugotna uloga ${ }^{61}$ To znači da nije moguća prestabilirana harmonija između Riječi Božje u najvlastitijem smislu te Riječi, to jest Riječi Božje u samoj objavi, i Riječi Božje u crkvenom navještaju. Upravo je zato razumljivo da iz Barthove göttingenške dogmatike ne iščezavaju izričaji karakteristični za njegov raniji opus, a kojima se opisuje privremenost, krhkost i nesavršenost navještaja Crkve te da se kroz čitavu dogmatiku ponovno provlači opisivanje tog navještaja kao »pothvata « (Wagnis) čiji je identitet s objavom u svakom trenutku ovisan o ispunjenju Božjeg milosnog obećanja. ${ }^{62}$ Ali u isto vrijeme i pothvata kojeg se kršćanska Crkva ni u jednom trenutku ne treba i zapravo ne smije odreći te pothvata za koji je upravo ona opunomoćena i to istim onim kanonom prema kojemu se njezin navještaj treba mjeriti. ${ }^{63}$

${ }^{60}$ Usp. isto, 19. Barth je u tom pogledu vrlo odrješit: »Jedna Božja riječ, jedan autoritet, jedna istina i jedna sila - no ipak ne jedno ime, nego tri. Tri Božja imena, u objavi, u Pismu, u propovijedi - a ipak to nisu tri Božje riječi, autoriteta, istine, sile, nego jedno. Pismo nije objava, nego je iz objave, a propovijed nije ni objava ni Pismo, nego je iz jednoga i drugoga. No Božja riječ jednako je tako Pismo kao i objava, a propovijed jednako koliko i Pismo... Božja je riječ u jednakoj uzvišenosti prvo i drugo i treće $(. ..) . \ll($ Isto.)

${ }^{61}$ Barth: »Ne apstrahiramo li ovdje od neposrednih svjedoka objave, što je ovdje itekako preporučljivo ne želimo li prikriti problem, onda moramo reći da za Crkvu uvijek nešto stoji između nje i same objave, nešto što njezin odnos prema objavi čini nemogućim ili pak mogućim. To je, kao prvo, vrijeme - sasvim grubo rečeno - fatalna previranja i nizanja povijesti, 'odurni jaz' o kojemu je Lessing toliko toga imao za reći (...), neporeciva činjenica da ona nije, kao ni svi mi, vidjela uskrsloga Krista, da se on nama nije prikazao. $\ll$ (Isto, 246s.)

${ }^{62}$ Usp. isto, 55., 58s.

${ }^{63}$ Barth: »Ovdje se o Bogu ne govori na svoju ruku ili na osnovi vlastita znanja, vlastita mišljenja ili vlastita autoriteta, i nipošto se ovdje ne iznosi nekakva autonomna spoznaja, filozofija pa čak ni filozofija religije, ne govori se ovdje ni iz nadahnuća ili ekstaze (...), nego zato što se u kanonu govori o Bogu, i s obzirom na taj kanon tvrdimo kako nam je zabranjeno ne govoriti o Bogu.« (Isto, 65s.) 


\section{Rimokatoličanstvo kao teološka opcija u kojoj su vrijednosti reformacijske teologije sačuvane bolje $i$ jasnije nego $u$ novoprotestantizmu}

Kako prije razdoblja svoga djelovanja u Göttingenu tako i tijekom cijeloga ovog razdoblja, ali i do kraja svoje teološke karijere, Barth ostaje nepokolebljivi kritičar novoprotestantizma. ${ }^{64}$ Međutim, njegov stav prema rimokatoličanstvu koji se, kao što je prije pokazano, počeo formirati u kontekstu njegove kritike novoprotestantizma, postupno se mijenja. Ta je pak promjena u prije svega povezana s pomakom u Barthovu razumijevanju osnovnih karakteristika protestantizma koji je vjeran autentičnoj reformacijskoj ideji.

Naime, kako u ranijoj fazi Barthova predavačkog djelovanja u Göttingenu (1921. - 1922.), tako i u njegovoj kasnijoj fazi (1923. - 1925.), njegovo je razmišljanje o rimokatoličanstvu uklopljeno u njegovu potragu za autentičnim protestantskim identitetom, odnosno u njegov pokušaj definiranja tog identiteta. Upravo je zato i promjena u Barthovu definiranju reformacijskim načelima vjernog protestantizma utjecala i na njegov stav o sadržaju i opsegu razlika između reformaciji vjernog protestantizma i rimokatoličanstva, a time i na sam njegov stav o rimokatoličanstvu.

Tako se - za razliku od tekstova s početka Barthova djelovanja u Göttingenu u kojima se predodžbi o reformaciji vjernom protestantizmu kao obliku crkvenosti, teologije i pobožnosti, koji je obilježen permanentnom krizom, suprotstavlja predodžba o rimokatoličanstvu kao crkvenosti, teologiji i pobožnosti koju odlikuje samosvijest i osjećaj sigurnosti - u Barthovoj göttingenškoj dogmatici razlika između reformaciji vjernog protestantizma i rimokatoličanstva predstavlja kao razlika u različitom poimanju sigurnosti, odnosno izvjesnosti Riječi Božje u crkvenom navještaju. Služeći se Barthovim izričajem iz predgovora Heppeovoj dogmatici o tome kako mu je upravo ta dogmatika pomogla da se i sam nađe $\gg$ u prostoru Crkve $\ll{ }^{65}$, moglo bi se također reći da se, prema Barthovim kasnijim radovima u Göttingenu, razlike između rimokatoličke i protestantske teologije mogu opisati kao različito poimanje sigurnosti koja je uvijek sigurnost u prostoru Crkve.

Naime, kao što je ranije pojašnjeno, sigurnost koja je primjerena autentičnom protestantizmu može se, prema Barthovoj prvoj dogmatici, opisati kao povjerenje u mogućnost Božje Riječi u navještaju Crkve. Pri tom se odlučno odbija bilo kakva ideja o prestabiliranoj harmoniji između čina objave i govora Crkve, a tvrdi se kako

\footnotetext{
${ }^{64} \mathrm{O}$ tome upečatljivo govori već i sam uvid u registar pojmova Barthove Crkvene dogmatike. Vidi pojam »Neuprotestantismus « u: Die Kirchliche Dogmatik von Karl Barth, Zürich, 1970., 263.

${ }^{65}$ Usp. H. HEPPE, Die Dogmatik der evangelisch-reformierten Kirche, VIs.
} 
se vjernost ovog govora uvijek iznova mora i preispitivati na kanonu kao svjedočanstvu o objavi prvotnih svjedoka Riječi.

Premda je to već implicirano u do sada rečenom, ovdje je potrebno napomenuti kako Barth ne poima autoritet kanona, odnosno Biblije u odnosu na navještaj Crkve, u smislu da bi Biblija predstavljala svojevrsni produžetak Kristova autoriteta - analogno shvaćanju Crkve u rimokatoličkoj teologiji koja, predstavljena u papi i učiteljstvu, stoji u kontinuitetu s Isusom. Narav Svetog pisma narav je svjedočanstva te upravo zato Barth i naglašava kako nije primjereno tvrditi da je reformacija rimokatoličko poimanje autoriteta pape ili crkvene hijerarhije zamijenila analognim poimanjem biblijskog autoriteta. I u tom pogledu Barth se sasvim vidi na tragu reformacijske teologije, jer njezina namjera nije bila učiniti od Biblije protestantsku inačicu papina autoriteta. Premda se takav neprimjereni razvoj reformacijskog shvaćanja Biblije doista i javio u dijelovima protestantizma, a poznat je kao biblicizam ili bilijski fundamentalizam, pri čemu je, prema Barthu, djelomično odgovorna upravo protestantska ortodoksija sa svojim naučavanjem o verbalnoj inspiraciji Biblije - on nikako nije primjeren. ${ }^{66}$

Barth i sasvim precizno opisuje pojedine momente autoriteta kršćanske Crkve upravo u povezanosti tog autoriteta s autoritetom kanona. Tako je prvi moment samo ustanovljivanje kanona koje je bilo vjernički čin upravo kršćanske Crkve. ${ }^{67}$ Drugi je pak ustanovljivanje mjerodavne verzije pojedinih kanonskih tekstova, a što, prema Barthu, ne može biti prepušteno samoj teološkoj znanosti. ${ }^{68}$ Treći moment autoriteta Crkve, odnosno povezanosti ovog autoriteta s autoritetom Pisma, jest njegovo tumačenje koje se uvijek događa u vjerničkoj zajednici - i to kako u prošlosti tako i u sadašnjosti. ${ }^{69}$

Kao što je napomenuto, unatoč ovakvom visokom vrednovanju autoriteta kršćanske Crkve, Barth se jasno i nedvosmisleno odmiče od razumijevanja govora Crkve kao apriori neupitnog nastavka same objave, a koje se, prema njegovu shvaćanju,

\footnotetext{
${ }^{66}$ Barth: »Prije svega, na osnovi takvog komparativnog promišljanja ne dolazi u obzir shvaćanje Pisma kao vjerske isprave, kao najizvornijeg i stoga normativnog dokumenta o povijesnim počecima kršćanstva. Kao da bi dokument u tom smislu, bez obzira na to o čemu svjedočio, mogao biti mjerodavan za ono što bi objava trebala ili ne bi trebala biti za nas koji živimo na vlastitu odgovornost! Kao da bi takav most bio dovoljno čvrst da prenese teret objave iz prošlosti u sadašnjost ili pak nas iz bezobjavne sadašnjosti u onu prošlost! « (Isto, 250s.)

${ }^{67}$ Usp. isto, 183., 281. Zanimljivo je da Barth ostavlja principijelno otvorenom i mogućnost revidiranja kanona. Ipak, tako nešto nikako ne bi bilo dopustivo pojedincu ili nekom dijelu kršćanske Crkve, nego isključivo Crkvi kao cjelini. (Usp. isto, 183s.)

${ }^{68}$ Isto, 285 ss.

${ }^{69}$ Usp. isto, 288.
} 
zastupa u rimokatoličanstvu. Jer sigurnost 'u prostoru Crkve' koju, prema Barthovu mišljenju, zastupa katoličanstvo, ona je sigurnost koja počiva na ideji Crkve kao svojevrsne premosnice, odnosno mosta između objave i sadašnjosti, pri čemu je ta sama premosnica - unatoč mogućnosti da neki njezini dijelovi ili pojedinci i postanu upitnima - u cjelini zapravo uvijek neupitna. ${ }^{70}$

U tom pogledu, rimokatoličanstvo je i dalje, prema Barthovu mišljenju, srodno novoprotestantizmu kao i svim prethodnicama novoprotestantizma - među kojima posebno mjesto pripada spiritualističkim kasnosrednjovjekovnim pokretima koji su se zatim slili u najrazličitije tipove protestantskog »zanesenjaštva $\ll u$ vrijeme same reformacije te $\mathrm{u}$ stoljećima nakon nje. ${ }^{71}$ Razlika između rimokatoličanstva i različitih novoprotestantskih inačica u tome je što ono poistovjećuje objavu i Crkvu, dok ove inačice poistovjećuju objavu sa samom poviješću, odnosno ljudskom religioznošću. Ipak, sa svojom idejom o autoritetu vjerske zajednice, rimokatoličanstvo je - prema Barthu - ipak daleko manje problematično od novoprotestantizma i njegovih raznovrsnih inačica te, upravo zato, može i treba postati važan partner $u$ dijalogu autentičnom protestantizmu i, štoviše, biti svojevrsnim podsjetnikom na njegov poljuljani i dijelom čak zaboravljeni identitet. To je tako jer put izlaska iz krize suvremenog protestantizma nije u borbi protiv ideje o autoritetu Crkve te u nepromišljenom suprotstavljanju crkvenome autoritetu slobode pojedinca i njegove religijske samosvijesti, nego u borbi za nastojanje da se autoritet Crkve primjereno shvati te da se sloboda pojedinca dovede $u$ ispravan odnos prema autoritetu Crkve, odnosno autoritetu zajedništva. A u tom pogledu rimokatoličko shvaćanje tog autoriteta ima potencijal za kvalitetan međukonfesionalni dijalog. ${ }^{72}$

${ }^{70}$ Barth doslovno kaže: »Prema katoličkom je nauku (...) Crkva (...) kao takva most, ili bolje rečeno ravna cesta koja nas vodi iz objave - i u objavu. Crkva je u neposrednom odnosu s objavom. Čak i ako je vjeru i poslušnost pojedinca potrebno neprestano obnavljati i iznova utemeljivati, Crkva kao takva, koja omogućuje zadovoljenje te potrebe, utemeljena je neupitno i nedijalektički direktno.« (Isto, 247.)

${ }^{71}$ Usp. isto, 252ss. Barth se pritom poziva na samu teologiju reformacije, a osobito na samog Luthera, koji je protestantske »zanesenjake « te njihovu zamisao o izravnom govoru Duha Božjeg pojedincu i to bez posredovanja ikakvih izvanjskih autoriteta, rado uspoređivao s rimokatoličkim poimanjem autoriteta Crkve u smislu njezina seberazumijevanja u izravnom kontinuitetu sa samim događajem objave. (Usp. isto.) Pritom je, prema Barthu, reformacijsko razumijevanje Svetog pisma kao prvorazrednog svjedočanstva o objavi 'lijek' kako za rimokatoličko predimenzioniranje autoriteta Crkve (koje dolazi do izražaja u razumijevanju Crkve kao takve koja stoji u kontinuitetu sa samom objavom) tako i za 'zanesenjačko' (a tako i novoprotestantsko) predimenzioniranje autoriteta pojedinca koji se nesamokritički poziva na izravan govor Duha Svetoga u vlastitoj unutrašnjosti, odnosno na svoj vlastiti religijski osjećaj kao krajnji autoritet. (Usp. isto, 319ss.)

${ }^{72}$ Usp. isto, 306. 


\section{Zaključak}

Ne umanjujući važnost Barthovih spisa prije njegova stupanja u zvanje honorarnog profesora na Sveučilištu u Göttingenu, moguće je reći da vrijeme Barthova akademskog djelovanja kao honorarnog profesora u Göttingenu (1921. - 1925.), gledano u cjelini, predstavlja formativno razdoblje njegove teologije. To je tako, jer u ovom razdoblju po prvi put dolazi do izražaja Barthova cjeloživotna teološka motivacija - a to je pronalaženje izlaska iz krize sebi suvremenog protestantizma na razini teološke artikulacije kakvu Barthov opus do tada nije poznavao. Sasvim je sigurno da je ovakvom podizanju razine artikulacije temeljna Barthova stava doprinijela i sama činjenica autorova stupanja u zvanje profesora teologije. Jer to je zvanje zahtijevalo od Bartha da nadiđe razinu biblijskog komentara, prigodnih teoloških tekstova i propovijedi, te da svoje teze i brige u vezi s krizom suvremenog protestantizma pokuša postaviti u širi povijesno-teološki kontekst te ih sustavnije promisliti. Za Bartha je to značilo propitati i same početke protestantizma u kontekstu teologije reformacije, ali i razdoblja teologije koje je reformaciji prethodilo, a to je teologija srednjeg vijeka. Upravo zahvaljujući ovim naporima i traženjima istinskog protestantskog identiteta, Barth u svom opusu otvara jednu sasvim novu temu: rimokatoličanstvo. I to najprije posrednim putem, to jest preko izučavanja teologije srednjeg vijeka, kojoj se posvetio ponajprije tijekom priprema svojih predavanja o Calvinovoj teologiji, a potom i sve izravnije: promatrajući i sámo rimokatoličanstvo.

Pritom Barth dolazi do dvije osnovne teze. Prva je teza o srodnosti novoprotestantizma i rimokatoličanstva, odnosno teza o tome da srednjovjekovna teologija, barem u jednom važnom dijelu, svoj kontinuitet ne živi samo u suvremenom rimokatoličanstvu, već i u novoprotestantizmu kojemu je svojevrsni uzor i prethodnica. Premda je Barth kritizirao novoprotestantizam i u svojim prijašnjim tekstovima, ukazivanje na analogiju između novoprotestantizma, s jedne strane, te srednjovjekovne odnosno rimokatoličke teologije, s druge strane, predstavlja novinu u odnosu na njegov dotadašnji opus. Ukazivanje na tu analogiju - koje ostaje kod Bartha prisutno u cijelom göttingenškom razdoblju, ali i u njegovoj kasnijoj teologiji - ima svoje faze i nijanse. U tom je smislu osobito zanimljivo upravo razdoblje Barthove profesure u Göttingenu.

Tako Barth u prvoj fazi svoga djelovanja u Göttingenu (1921./1922.) govori o srednjovjekovnoj, odnosno rimokatoličkoj teologiji kao o svojevrsnoj 'herezi' koja je, premda daleko impozantnija i kao takva vrijedna poštovanja i divljenja, jednako problematična kao i novoprotestantska hereza. Osnovna je pritom razlika između srednjovjekovne teologije te rimokatoličanstva kao njezina sljedbenika u tome što je u rimokatoličanstvu riječ o poistovjećivanju objave s govorom Crkve, a u no- 
voprotestantizmu o poistovjećivanju objave s ljudskom religioznošću. Druga faza Barthova djelovanja u Göttingenu obilježena je polaganim zaokretom u vrednovanju rimokatoličanstva i to tako da se njegova 'heretičnost' smatra manje problematičnom od novoprotestantske te se pritom rimokatoličko vrednovanje autoriteta Crkve promatra kao istinski potencijal za promišljanje o autentičnom protestantskom identitetu. Razlog takvog zaokreta bio je ponajprije taj što je Barth, izučavajući povijest reformacije te uopće povijest protestantske teologije, došao do zaključka da bit autentičnog te reformaciji vjernog protestantizma nije u suprotstavljanju slobode pojedinca autoritetu Crkve, nego u uvažavanju činjenice autoriteta crkvenog govora u povijesti i u sadašnjosti te u uočavanju granica autoriteta Crkve. Osnovne pak konture tih granica dalo je, prema Barthu, reformacijsko razumijevanje autoriteta Svetog pisma koje treba razumjeti kao korektiv i rimokatoličkom poimanju autoriteta Crkve, i novoprotestantskom poimanju slobode pojedinca. Utoliko je rimokatoličko poimanje autoriteta Crkve daleko prihvatljivije od novoprotestantskoga te ga, kao takvog, protestantizam može i treba uzeti kao podsjetnik na svoj identitet te kritički korektiv svojih stranputica u ovom pogledu - i to kako u svojoj povijesti tako i u sadašnjosti.

Misao o rimokatoličanstvu kao kršćanskoj konfesiji koja može biti od pomoći upravo protestantizmu u krizi identiteta, u razdoblju Barthova djelovanja u Göttingenu izražena je uglavnom načelno. Ta će misao svoju konkretniju primjenu dobiti tek u razdoblju Barthova djelovanja u Münsteru (1925. - 1930.) i to osobito u dvama predavanjima izričito posvećenima pitanju odnosa između protestantskoga i rimokatoličkog identiteta. Riječ je o predavanju Der Begriff der Kirche ${ }^{73}$ te predavanju Der römische Katholizismus als Frage an die protestantische Kirche $e^{74} \mathrm{u}$ kojima Barth proširuje dijalog s rimokatoličanstvom, a pritom se posebno osvrće na protestantsko-rimokatoličke razlike u pitanjima ekleziologije te u pitanjima nauka o milosti. Barthova ideja o rimokatoličanstvu kao podsjetniku na autentični protestantski identitet svoju će sustavnu primjenu dobiti tek u tridesetim godinama dvadesetog stoljeća u njegovoj monumentalnoj Crkvenoj dogmatici. O tome da je kod Karla Bartha tema rimokatoličanstvo - kako glede opsega tako i glede kvalitete i slojevitosti razrade pojedinih pitanja - 'došla na svoje' tek u Crkvenoj dogmatici, upečatljivo svjedoči već i sam površni uvid u registar pojmova uz pojedine sveske ovog djela. No osnovne konture Barthova promišljanja o rimokatoličanstvu te o odnosu između rimokatoličke i protestantske teologije, koje su ocrtane u vrijeme njegova djelovanja u Göttingenu, prepoznatljive su i u Barthovoj Crkvenoj dogmatici kao i u

${ }^{73}$ Usp. K.BARTH, Der Begriff der Kirche (1927), u: ISTI, Vorträge und kleinere Arbeiten (19251930), H. Schmidt (ur.), Zürich, 1994., 140.-159.

${ }^{74}$ Usp. K. BARTH, Der römische Katholizismus als Frage an die protestantische Kirche (1928), u: ISTI, Vorträge und kleinere Arbeiten (1925-1930), H. Schmidt (ur.), Zürich, 1994., 303.-343. 
drugim kasnijim radovima. Upravo zato Barthovu göttingenškom razdoblju pripada trajna važnost kao formativnom razdoblju za artikuliranje ove njegove ključne teme, važne i za protestantizam u cjelini, a time i za kršćansku ekumenu. 


\title{
THE RELATIONSHIP TOWARDS ROMAN CATHOLICISM IN THE EARLY WORKS OF KARL BARTH
}

\author{
Lidija MATOŠEVIĆ*
}

Summary: The article discusses the question of the relationship of the Protestant theologian Karl Barth towards Roman Catholicism. It focuses on the period of Barth's occupation as a part-time professor at the Department of Reformed Theology at the University of Göttingen. It is a formative period both for Barth's theology as a whole, as well as for his relationship towards Roman Catholicism. The article presents the genesis of Barth's interest in Roman Catholicism by placing it in the context of his dealing with Protestant theology itself and its history, or pre-history in the theology of the Middle Ages. The article shows how Barth's attitude towards Roman Catholicism changed - from understanding Roman Catholicism as a kind of 》heresy « similar to New Protestantism, to understanding Roman Catholicism as a form of theology and ecclesiastics whose, although problematic understanding of the possibility of the Word of God in the discourse of the Church, can become a critical stimulus to Protestant theology and ecclesiastics in search for its partially obscure identity.

Keywords: Karl Barth, Reformation Theology, Protestantism, New Protestantism, Roman Catholicism, Revelation, Scripture, Church Authority.

\footnotetext{
* Asst. Prof. Lidija Matošević, Ph. D., Center for Protestant Theology Matija Vlačić Ilirik, University
} of Zagreb, Ivana Lučića 1A, 10000 Zagreb, Croatia, lidija.matosevic@tfmvi.hr 